\title{
QUINTUS CICERO'S ASTRONOMY?
}

Among the Eclogues of Ausonius, we find a fragment of astronomical poetry, attributed in its superscription to Quintus Tullius Cicero, the brother of the orator. The Quintus fragment has survived by a twist of fate. It was preserved because it was included, perhaps by accident, among the Eclogues of Ausonius, in a single manuscript, V (Leid. Voss. Lat. 111). ${ }^{1}$ The Quintus fragment represents a reasonably lengthy piece of Republican poetry, written in a period when there are many gaps in our record; otherwise, perhaps, we might believe it unworthy of much excitement. Yet some excitement might indeed be merited, since, if it is by Quintus, it surely represents one of the earliest zodiac lists in Latin, after that of Marcus Cicero, in his Aratea ${ }^{2}$ So too, it might be worthy of more than a little suspicion, and in this article I propose to reassess its date and attribution.

For reasons I shall argue below, it seems fairly clear to me that this is not one, but two fragments, transposed, then juxtaposed by the closing-up of a lacuna between them. These may plausibly come from a translation of Aratus, one from an earlier part, one from a later part. I shall tentatively suggest that these fragments may have been by Marcus Cicero rather than by his brother, and belong to the Aratea.

Such speculation is perilous, however, not least because, once we have done away with the certain authorship of Quintus Cicero, we open up a receding vista of possibility. Our fragment may be attributed to Marcus; this would at least keep it in the Republican period. But (I shall argue) there is little firm evidence available for dating our fragment before Ausonius (A.D. c. 490); indeed, were it not for the Ausonian superscription, which almost certainly indicates that Ausonius himself wrote our poem down, there would be no firm evidence for assigning to it a date earlier than the writing of $\mathrm{V}$, in about A.D. 800.

\footnotetext{
* My sincere thanks go to the Kudos Foundation for their support during the time this article was written, and to those of my friends and colleagues who have listened to or read it, particularly John Ramsey and Frances Muecke. I also thank Miriam Griffin as editor of $C Q$, and the readers, for their helpful comments.

${ }^{1}$ On V, see S. Tafel, 'Die vordere, bisher verloren geglaubte Hälfte des vossianischen Ausonius-Kodex', RhM 69 (1914), 630-41; H. de la Ville de Mirmont, Le manuscrit de l' ̂̂le Barbe (Bordeaux-Paris, 1917-19); F. Della Corte, 'L'Ordinamento degli Opuscula di Ausonio, RCCM 2 (1960), 21-9; S. Prete (ed.), Decimi Magni Ausonii Burdigalensis opuscula (Leipzig, 1978), xv; K. A. De Meyier, Codices vossiani latini (Leiden, 1973), 235-40; M. D. Reeve, 'Ausonius', in L. D. Reynolds (ed.), Texts and Transmission (Oxford, 1983), 26-8; A.-M. Turcan-Verkerk, 'L'Ausone de Iacopo Sannazaro: un ancien témoin passé inaperçu', Italia medioevale e umanistica 43 (2002), 231-312. The MS originated in the Scriptorium at Lyon, and is dated to the first half of the ninth century.

2 On Cicero's Aratea, see E. Gee, 'Cicero’s astronomy', CQ 51 (2001), 520-36. The present article is in some sense its companion-piece.
} 
Despite its initially tenuous hold on life, our fragment is now accessible in two forms: among Ausonius' Eclogues, ${ }^{3}$ and in collections of Latin fragments. ${ }^{4}$ I quote Courtney's text: ${ }^{5}$

Auson. Ecl. 25, p.114 Prete = App. A.8, p.705 Green:

Quinti Ciceronis hi versus eo pertinent ut quod signum quo tempore inlustre sit noverimus; quod superius quoque $(E c l .16$, p. 108 Prete $=9$, p. 100 Green $)$ nostris versibus expeditur:

flumina ${ }^{6}$ verna cient obscuro lumine Pisces curriculumque Aries aequat noctisque dieique, cornua quem condunt florum praenuntia Tauri. aridaque aestatis Gemini primordia pandunt longaque iam minuit praeclarus lumina Cancer languificosque Leo proflat ferus ore calores. post modium quatiens Virgo fugat orta vaporem, autumni reserat portas aequatque diurna tempora nocturnis dispenso sidere Libra, ecfetos ramos denudat flamma Nepai. pigra Sagittipotens iaculatur frigora terris, bruma gelu glacians iubar it ${ }^{7}$ spirans Capricorni, quem $^{8}$ sequitur nebulas rorans liquor altus Aquari. tanta supra circaque vigent †umi at dextra laevaque ciet rota fulgida Solis

mobile curriculum et Lunae simulacra feruntur

squama sub aeterno conspectu ${ }^{10}$ torta Draconis eminet. hunc infra fulgentes Arcera septem magna quatit stellas, quam servans serus in alta conditur Oceani ripa cum luce Bootes.

These lines of Quintus Cicero tell us which star-sign is shining at which season, as has also been expounded previously in my poetry:

${ }^{3}$ Prete (n. 1); K. Schenk1 (ed.), D. Magni Ausonii opuscula (Berlin, 1883; repr. 1961), R. Peiper (ed.), Decimi Magni Ausonii Burdigalensis Opuscula (Leipzig, 1886); and R. P. H. Green (ed.), The Works of Ausonius (Oxford, 1991). The place of the fragment in the Ausonian corpus is disputed; some take it as a fully paid-up Ausonian Eclogue (Prete, for example, in whose numeration it is Eclogue 25), while others relegate it to an annexe (Green placing it as no. 8 in his Appendix A).

${ }^{4}$ P. Burman (ed.), Anthologia Veterum Latinorum Epigrammatum et Poematum (Amsterdam, 1759-73), 5.41; H. Meyer (ed.), Anthologia Veterum Latinorum Epigrammatum et Poematum (Leipzig, 1835), no. 66; F. Buecheler and A. Riese (edd.), Anthologia Latina (Leipzig, 1894/1906), 1.1/1.2, no. 642; K. Buechner (ed.), Fragmenta Poetarum Latinorum (Leipzig, 1982), 101; W. Morel (ed.), Fragmenta Poetarum Latinorum ${ }^{2}$ (Leipzig, 1927), 79; E. Courtney, The Fragmentary Latin Poets (Oxford, 1993), 179-81. It is also reproduced in F. Buecheler (ed.), Quinti Ciceronis Reliquiae (Leipzig, 1869), 68f. The main medium through which the fragment is now widely known is perhaps H. W. Garrod (ed.), The Oxford Book of Latin Verse (Oxford, 1912), and it is this version (stopping at line 16) which is published on the internet.

${ }^{5}$ With one variant, the manuscript reading flumina for flamina in line 1 . The variants I give elsewhere in the notes are selective: for full apparatus, see Courtney (n. 4). The translation is my own.

${ }^{6}$ Flumina cod. (Leid. Voss. Lat. 111); flamina Wakefield: see Courtney (n. 4).

${ }^{7}$ It Schenkel (n. 3), est cod.; cf. Buecheler (n. 4), 69.

${ }^{8}$ Quam cod.

9 Tanta supra circaque urgentur lumina mundi (Buecheler, n. 4); tanta supra circaque vigent haec lumina mindi (Buechner, n. 4); tanta supra circaque vigent tunc flumina mundi (Prete, n. 1).

${ }_{10}$ Aeterno V; aetherio Heinsius; sub Arctoo conspectu Scaliger (Buecheler [n. 4], 69). 
The Fish summon the spring rivers with their dim light;

Aries makes equal the course of night and day;

He is hidden by Taurus' horns, harbingers of flowers.

The Twins open the dry beginning of summer,

Next illustrious Cancer shortens the long days,

And fierce Leo breathes out from his mouth enervating heat.

Then Virgo rises, and, shaking her measuring-vessel, puts the heat to flight.

Libra with equally balanced star unlocks the gates of autumn,

Making the hours of day equal those of night.

The fire of Scorpio strips the spent branches.

The Archer shoots numbing cold to earth.

Winter, turning rigid with frost, comes, the windy star of Capricorn (?);

Following him on high, the moist constellation of Aquarius bedews the clouds.

These are the great lights of heaven, which hurry in their circular paths up above. $^{11}$

But on the right hand and on the left

The bright wheel of the sun drives on its rapid chariot,

And the moon, its reflection, is carried along.

Draco raises up his scaly coil in constant view;

Below him, the great Wagon shakes its seven shining stars;

Guarding it, Bootes at dawn is hidden late in the deep River of Ocean. ${ }^{12}$

Our fragment begins as a list of Zodiacal constellations and the seasons accompanying them. But this is followed by three apparently transitional lines (14-16), then an editorial lacuna, ${ }^{13}$ and then the beginning of a different list of constellations, non-zodiacal ones (17-20).

Cleverly enough, the poet has rendered the zodiacal constellations with attributes indicative of their seasonal status. This enables him to represent weather in pictorial form, while playing with words and sounds: note ore calores (6), the mouth of Leo being related, in terms of the visual word, to the heat it generates; and the alliterative servans serus (19), of Bootes staying up late on night watch.

Close reading of the fragment shows it to contain a combination of the prosaically meteorological and the self-consciously poetic. This is exemplified in lines $6 \mathrm{f}$. Languificus in line 6 is a highly poetic compound form, and a hapax legomenon. On the other hand, modium, 'measuring vessel', in line 7 , is prosaic and agricultural. ${ }^{14}$

11 Translating the reading of Buecheler (see n. 9).

12 I wonder whether to omit Courtney's full stop, following Buecheler, and take cum as temporal; in this reading a verb would have to come in the following line in a more extensive original. Cum luce as 'with its light' seems awkward; I have provisionally translated as 'at dawn', i.e. with (the coming of light), since that is when Bootes sets (Aratus, Phaen. 581-5).

${ }_{13}$ Buecheler (n. 4), 69, first posited a lacuna: hi versus tam laxe cum superioribus cohaerent ut dubites num eodem modo Quintus eos continuaverit. Schenkl (n. 3), 17 doubted whether the two parts were from the same poem: qui secuntur vv. 17-20 fragmentum sunt carminis nullo vinculo cum Q. Ciceronis versibus coniuncti (see also Buechner [n. 4], 102). Courtney (n. 4), 181, says, 'I suspect that after 14 a passage of transition from the ecliptic (through the Zodiac) to the tropics and then the equator is missing.' Green (n. 3), 705, is conciliatory: 'The last four lines of the fragment do not cohere with what precedes, but their style and content is similar.' I do not discount Schenkl's hypothesis that the last four lines of our fragment may be from a different poem, by a different author, simply tacked on to Quintus' piece on the Zodiac (lines 1-16); however, I here choose to argue a hypothesis which tries to demonstrate the unity of all of the lines in the fragment as we have it, within a wider context.

${ }^{14}$ Compare e.g. Lucilius 322 (frumentarius est, modium hic secum . . affert); Varro, Men. 245 and Rust. 1.7.3, 1.37.4 (dolium ac modium); Cic. Att. 6.1.16 (pleno modio), and Hor. Epist. 1.16.55 (fabae). 
Quintus' treatment of Virgo shaking a measuring vessel is unusual. She is never thus represented elsewhere, usually depicted holding an ear of wheat, Spica or Spicum, the brightest star in the constellation. ${ }^{15}$ But the image of a rustic Virgo holding a measuring-jar works well here, since these lines play especially on the idea of measuring. Dispenso in 9 means literally 'equally measured out' (the $T L L$ gives the gloss quasi aeque lance perpendere for dispendo), but also perhaps plays on the verbal idea of pendere - the star is 'hanging' in the balance (of Libra, the Scales). ${ }^{16}$ This is because Libra is the sign of the Autumn Equinox, the time when night and day are 'balanced out' (aequatque, line 8). Quintus thus connects two successive zodiacal constellations, Virgo and Libra, by the idea of measurement, usually attached only to the latter as the equinoctial sign. ${ }^{17}$

Lunae simulacra in line 16 is equally unusual. The expression may mean that the moon reflects the sun's rays, or that it is a 'shadowy' object; but simulacrum of the heavenly bodies is rare. Ovid uses it thus, but of the constellations, not the moon, in one fragment of his translation of Aratus' Phaenomena. ${ }^{18}$

Arcera, a 'covered wagon', in line 18, occurs as early as the Twelve Tables, but it denotes a star-sign, the Great Bear, only in our fragment. ${ }^{19}$ Whereas Marcus, in Aratea fr. V (Soubiran), had used the established Roman name for the Bears, Septem Triones ${ }^{20}$ Quintus uses the archaic word arcera to render the Greek $\alpha^{\prime \prime} \mu \alpha \xi \alpha$. This is what Aratus had called the Bears at Phaenomena 27, playing on $\alpha^{\prime \prime} \mu \alpha$ and $\alpha \dot{\alpha} \xi \omega \nu$, the idea being that the Bears move in the sky together like the wheels at either end of an axle. Quintus has apparently tried to retain the sound and sense of the Greek name while drawing on 'authentic' Roman diction.

The verb cieo (1 and 15), with the sense of movere, agere, agitare, seems often to be used in the context of enquiry into nature. Lucretius used it at DRN 5.775f. of the forces controlling the moon and the sun (solis uti varios cursus lunaeque meatus I noscere possemus quae vis et causa cieret). Marcus Cicero uses the verb of cosmological forces at De Natura Deorum 2.23: omne, quod est calidum et igneum, cietur et agitur motu suo. With the sense of efficere, excitare, commovere, cieo can also be used specifically in the context of bad weather, as at Lucretius 6.376, tempestasque cietur turbida caelo. ${ }^{21}$ The same verb was used of the capacity of the Hyades to 'summon up' rain, by Cicero's learned freedman Marcus Tullius Tiro, quoted by Gellius:

'adeo', inquit, 'veteres Romani litteras Graecas nesciverunt et rudes Graecae linguae fuerunt, ut stellas, quae in capite Tauri sunt, propterea "suculas" appellarint, quod eas Graeci v́ádas vocant, tamquam id verbum Latinum Graeci verbi interpretamentum sit, quia Graece $\tilde{\epsilon} \epsilon$,

15 Cic. Aratea fr.16.6 (Soubiran): spicum illustre tenens, splendenti corpore Virgo. See also Vitruvius 9.4.1; Germanicus 97; Plin. $H N$ 18.311; Columella 11.2.

16 D. R. Shackleton Bailey, Towards a Text of Anthologia Latina, Cambridge Philological Society suppl. 5 (Cambridge, 1979), 67, proposed suspenso, 'poised', for dispenso, on the grounds that it 'would make better sense'. However, dispenso seems to me to fit well with the overriding idea of these lines, that of 'measuring out'.

17 Libra also represents the Autumn equinox, and the imagery of balance is exploited, in Virgil, G. 1.208 and Manilius 1.267, 2.242, and 3.659, and Sen. Herc. Fur. 844.

18 tot numero talique deus simulacra figura imposuit caelo, Ovid fr. 2; Courtney (n. 4), 308.

19 XII Tab. (= Gell. NA 20.1.25; see also 20.1.11 and 29f); Varro, Ling. 5.140. On the various names of the Great Bear, see A. Le Boeuffle, Les noms latins d'astres et de constellations (Paris, 1977), 82-9.

20 From Plautus, Amph. 273 onwards.

21 See also Aen. 8.354 (nimbos). 
"sues" Latine dicantur. sed $\dot{v} \alpha ́ \delta \epsilon s^{\prime}$ inquit 'o $\dot{v}^{\prime} \alpha^{\alpha} \pi \dot{o} \tau \hat{\omega} \nu \dot{v} \hat{\omega} \nu$, ita ut nostri opici putaverunt, sed ab eo, quod est $v_{\epsilon \iota \nu}$, appellantur; nam et cum oriuntur et cum occidunt, tempestates pluvias largosque imbres cient. $^{.22}$

The Romans of earlier times (he says) were so ignorant of Greek letters and uncultivated in the Greek language that they called the stars on the head of Taurus Suculae, 'Piglets', because the Greeks call them Hyades, as though this Latin word were a translation of the Greek word, because hyes (piglets) in Greek are called sues in Latin. But (he says) the Hyades are so called not from hyes, as our stupid countrymen thought, but from hyein ('to rain'); for when they rise, as well as when they set, they summon up rainy squalls and big storms.

Tiro's use of cieo is close to the expression in Quintus. Here (as usual in ancient meteorological astronomy) the stars have the capacity to create weather, rather than simply accompanying it, ${ }^{23}$ and, in the case of the Hyades, as with Leo in the Quintus fragment, this capacity is represented in their name.

Quintus and Tiro might have been talking the same meteorological language, but the main influence on Quintus was apparently his brother. In terms of general style, Quintus shares Marcus' inclination to word-repetition (cie $[n] t 1,15$; aequat 2, 8; curriculum 2, 16) and placement of lumina or -e in the fifth foot $(1,5,14) .{ }^{24}$ The star-names Quintus uses are generally those pioneered by Marcus: Pisces, Aries and Taurus as names of constellations occur first (so far as we know) in Marcus Cicero's Aratea, as do Gemini, Cancer, Leo and Virgo. ${ }^{25}$ Capricornus and Aquarius are also first used as star-names in Marcus Cicero's Aratea. ${ }^{26}$ Capricorn ends the hexameter at Aratea 273 and 311, as it does in Quintus' line 12.

On the other hand, Nepa in line 10 is the old name for Scorpio, occurring, for example, in Plautus, and among the fragments of Ennian drama, ${ }^{27}$ and is used by Marcus at Aratea 324 and 417 (in both cases in the archaic genitive form Nepai, as in

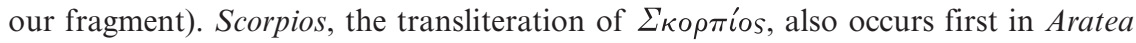
208, but, of the alternatives used by Marcus, Quintus has chosen the older. ${ }^{28}$ Conversely, Sagittipotens in 11, which looks archaic or Ennian, in fact only occurs (for the standard Sagittarius ${ }^{29}$ ) in Marcus Cicero (Aratea 73, 325, and 459) and in this fragment.

Quintus echoes his brother frequently in other respects. The phrase obscuro lumine (line 1) was used at Aratea 328-9, in Marcus' own zodiac list, of a different, but contiguous, constellation:

exim squamiferi serpentes ludere Pisces;

quis comes est Aries, obscuro lumine labens.

Next the twisting scaly fish dart; Aries, slipping along with a dim light, accompanies them.

22 M. Tullius Tiro apud Gellius, NA 13.9.4; P. K. Marshall (ed.), Aulus Gellius, Noctes Atticae, vol. 2: Books 11-20 (Oxford, 1968).

23 See also Gellius 14.1.9 pruinas et calores cient stellae.

${ }^{24}$ Courtney (n. 4) on Quintus' line 7.

25 See Le Boeuffle (n. 19), 152-66 and 181. There seem to have existed few Latin designations for constellations before Cicero's Aratea. Lists which include these exist (but rarely) in early Roman literature (e.g. Plautus, Amph. 273-5). Marcus Cicero seems to have been instrumental in developing Latin techniques of adapting Greek star-names.

${ }^{26}$ Each used eight times in the Aratea as extant: see Le Boeuffle (n. 19), 176-80.

27 Plautus (nn. 20 and 25); Ennius, Scaenica 242f. (p. 160 ed. Vahlen = 185-6 ed. Jocelyn).

${ }_{28}$ Nepa is perhaps Punic in origin: see Paulus Festus (ed. Mueller), 164 Nepa Afronum lingua sidus quod Cancer appellatur, vel, ut quidam volunt, Scorpios.

29 Also used by Marcus at Aratea 279. 
Quintus appears to have lifted the descriptive phrase obscuro lumine from Marcus' first Zodiacal constellation and applied it to his first, different, zodiacal constellation, in a clever variation of his brother. His procedure is similar at line 6, which applies to Leo a descriptive phrase used of Capricorn at Aratea 326: post hunc ore fero Capricornus vadere pergit, also in Marcus' zodiac list, which Quintus obviously had in mind here.

There are instances where Quintus echoes specific innovations made by Marcus. Praenuntius in line 3 occurs first in Marcus Cicero, Aratea 66, clari praenuntia solis. ${ }^{30}$ Aestatis primordia (line 4) is used at Aratea 39. Praeclarus in line 5, with its two senses of 'famous' and 'bright', had been similarly played upon by Marcus in Aratea fr. II.2 (Soubiran), praeclara insignia caeli, of the constellations generally. ${ }^{31}$ It is used of the stars by Marcus and Quintus alone.

Elsewhere, near-echo enables Quintus himself to innovate. Rota fulgida solis in 15 echoes Marcus Cicero, Aratea 281, rota fervida solis, but Quintus substitutes fulgidus, first here in Latin, for the older form fervidus, found as early as Accius. ${ }^{32}$

We can clearly see that Marcus Cicero's translation of Aratus, re-worked, provided almost all the expressions in our fragment. ${ }^{33}$ We should therefore ask whether this fragment is all that remains of a translation of Aratus' Phaenomena, which dealt with its model in the same way as Marcus Cicero's Aratea or (later) Germanicus' Phaenomena, rendering the Greek in a way which is reasonably complete, while making use of decorative variatio and Romanization of the original. If it is, it may be an important addition to the already significant corpus of Roman translations of the Hellenistic astronomical poet.

This possibility has sometimes been obfuscated by editorial practice, for example where the fragment is reproduced only as far as line 16. This is the case in The Oxford Book of Latin Verse, an accessible source, in which the casual reader might come across our poem. ${ }^{34}$ Stopping at line 16 gives the impression that Quintus deals only with the zodiac, which he does not. Thus also the misleading title 'Q. Cicero's De Duodecim Signis', which heads the only individual study of the poem..$^{35}$ In actual fact there are fifteen constellations in the complete fragment, and the last four lines deal with non-zodiacal constellations.

But the closeness of our fragment to Marcus Cicero's Aratea, which has been demonstrated, combined with its content, may support the hypothesis that this forms part of a larger Aratean translation. Despite limiting its content to the zodiac in his study of our fragment, in a later work Possanza seems to imply that our poem is in some sense a translation of Aratus, asserting that the Quintus fragment and Marcus Cicero's zodiac list at Aratea 320-33 'represent two possible ways in which [Germanicus] might have amplified Aratus' [zodiac] list'. ${ }^{36}$ Definition of 'translation' is, needless to say, problematic, since there exist many different translation styles among

30 Also of comets, at De Natura Deorum 2.14 nuper . . fuerunt calamitatem praenuntiae.

31 See also lines 9 and 371 of the Aratea. Marcus also refers to praeclara species Draconis at De Natura Deorum 2.107.

32 Accius, Trag. 582 fervido ardore solis.

33 It is interesting that Quintus does not echo only Marcus'Aratea but apparently his other poems as well. Line 16 of the fragment, squama sub aeterno conspectu torta Draconis, is close to Marcus fr. 23.11 Buechner (n. 4), vidimus inmani specie tortuque draconem, although the snake in Marcus' translation of Iliad 2.308-9 is terrestrial rather than celestial.

34 Above, n. 4.

35 D. M. Possanza, 'Two notes on Q. Cicero's De Duodecim Signis', CP 87 (1992), 44-6.

36 D. M. Possanza, Translating the Heavens (New York, 2004), 179. 
the Roman Arateans. One might compare the different approaches to the source text found in Varro of Atax, Virgil and Marcus Cicero, ranging from the literal to the allusive, sometimes in the same work. ${ }^{37}$ Marcus Cicero managed to end up with roughly the same number of lines as Aratus by means of extensive give-and-take: as Jean Soubiran put it, 'La quasi-égalité du modèle grec et de la version latine résulte moins du principe strict: 1 vers grec $=1$ vers latin, que d'une foule de variations en plus ou en moins, qui finissent par se compenser à peu près. ${ }^{38}$

Let us, for the sake of argument, consider how the Quintus fragment would shape up as part of a translation of Aratus. To work backwards, lines 17-20 describe the same stellar configuration as Aratus, Phaenomena 50-2, on the relative positions of the Bears and Draco. Here is the passage in which these lines occur, Phaenomena 45-54:

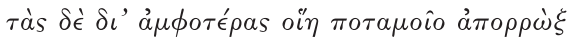

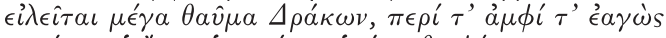

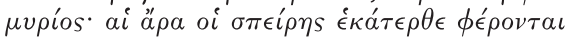

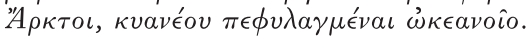

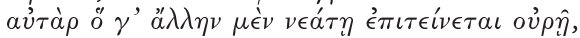

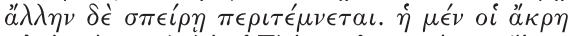

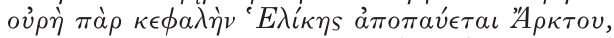

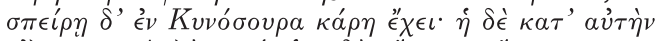

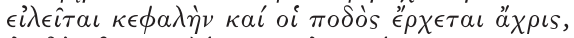

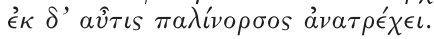

Between the two Bears, in the likeness of a river, winds a great wonder, the Dragon, writhing around and about at enormous length; on either side of its coil the Bears move, keeping clear of the dark-blue ocean. It reaches over one of them with the tip of its tail, [50] and intercepts the other with its coil. The tip of its tail ends level with the head of the Bear Helice, and Cynosura keeps her head within its coil. The coil winds past her very head, goes as far as her foot, then turns back again and runs upwards. ${ }^{39}$

Aratus line 52 might be rendered by Quintus 17-18, particularly if one translates these lines, 'the scaly coil of Draco rises up under her eternal gaze (i.e. that of Cynosura, the Great Bear)', a reading which Scaliger's conjecture on line 17, sub Arctoo conspectu, makes explicit. ${ }^{40}$ Quintus may have combined this with popular passages or topoi from other parts of Aratus, standard technique for the Latin Arateans. ${ }^{41}$ For example, line 19 (serus) alludes to Phaenomena 585, ó $\psi \dot{\epsilon} \delta v ́ o v \tau \iota$, in

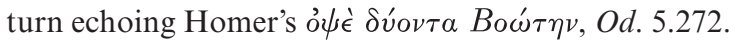

More significantly perhaps, Quintus may also work Aratus' wordplay into his translation, by playing bilingual games of the kind his brother liked. For example, at Phaenomena 91-3, Aratus implicitly derived Bootes, Boẃ $\eta s$, the Ploughman, from

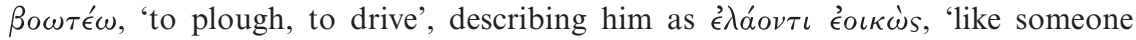
driving':

${ }^{37}$ See R. F. Thomas (ed.), Virgil, Georgics, vol. 1 (Cambridge, 1988), on Georgics 1.374-92. On Germanicus' various translation techniques, see Possanza (n. 36), ch. 1. On Roman 'translation' of Hellenistic models generally, see M. Fantuzzi and R. L. Hunter, Tradition and Innovation in Hellenistic Poetry (Cambridge, 2004), 444-85.

38 J. Soubiran (ed.), Cicéron: Aratea, fragments poétiques (Paris, 1972), 88. On Marcus' technique, see more recently Gee (n. 2).

${ }^{39}$ Text and translations of Aratus from D. Kidd (ed.), Aratus: Phaenomena (Cambridge, 1997).

40 See n. 10 above.

${ }^{41}$ On the prevalence of certain 'purple passages' from Aratus in Roman literature generally, see $\operatorname{Kidd}$ (n. 39), 41. 


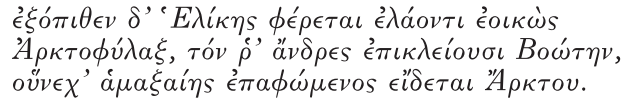

Behind Helice there comes, like a man driving, Arctophylax, whom men call Bootes, because he is seen to be just touching the Wagon-Bear.

Quintus, on the other hand, engages in his own etymology, describing Bootes as servans, 'guarding', a bilingual play on Arctophylax, the Bear-Guardian, Aratus' alternative designation for Bootes. ${ }^{42}$ This parallels Aratus' wordplay, formulating a response to it which hints at the alternative name of a constellation, and plays with a Latin semantic calque for that name.

Thus far, it seems possible to say that lines 17-20 of the Quintus fragment have been substantially influenced by Aratus. Turning to the Zodiac list which forms the greater part of the fragment, this may be compared with Aratus' sketch of the Zodiac, Phaenomena 544-52:

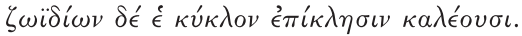

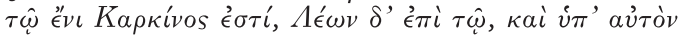

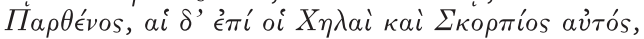

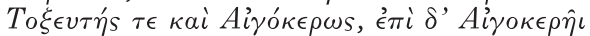

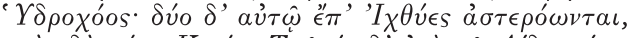

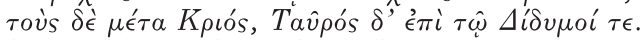

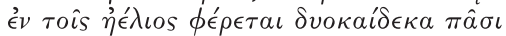

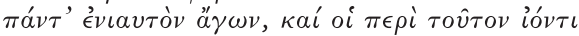

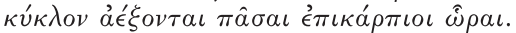

Men call it by name the circle of the Zodiac. On it is the Crab, and next the Lion, and under that the Maiden, after her the Claws and the Scorpion itself, the Archer and Capricorn, and after Capricorn the Water-pourer; after him the two Fishes are starred, after them the Ram, the Bull after that and the Twins. Through all these twelve signs goes the sun as it brings the whole year to pass, and as it goes round this circle, all the fruitful seasons increase.

Quintus has started at a different point in the circle of the Zodiac - with Pisces rather than Cancer ${ }^{43}$ - and Aratus' list is sparer. At the same time, the Quintus passage seems to be responding to something in Aratus, namely the notion of the seasonal year ( $\hat{\omega}$ pal, Aratus 552), and making this aspect of the Zodiac its theme: Aratus was about relative space, Quintus is about relative time.

If it is the case that our fragment may be plausibly said to have been part of a single larger work, and that this work may have been a translation of Aratus, we appear to be dealing not with one fragment, but with two. Following Aratus' order, Quintus' description of the Northern constellations (lines 17-20) would have been near the beginning of his work, the lines on the zodiac would have come later. Thus they have been transposed, since the Northern constellations should come before the zodiac. This might help explain the lack of continuity between lines 16 and 17 .

What is the evidence that Quintus Cicero could have written such a work? As previously stated, $\mathrm{V}$ of Ausonius is the only place where an astronomical fragment of Quintus appears; if this is his, it is the only surviving fragment of his poetry. ${ }^{44}$ There is

42 On the name Arctophylax, which occurs, like Bootes, first in Latin in Cicero's Aratea, see Le Boeuffle (n. 19), 94.

43 See Courtney (n. 4), 180.

44 Quintus' poetic output seems to mirror his brother's, being divided between epic, annals or commentarii of a 'traditional' kind on the one hand, and tragedies and other works related to 
no evidence, apart from Ausonius' authority, for Quintus' authorship of our fragment. Nor is there any evidence for Quintus as the author of a sustained astronomical poem in the manner of his brother's Aratea. It is true that the title Erigone finds place among Quintus' tragedies; ${ }^{45}$ the light-hearted reference to a dog in Cicero Ad Quintum Fratrem 3.7.7 indicates that this was the Erigone-myth in which the dog, catasterized, becomes Sirius, and its mistress, Virgo. ${ }^{46}$ However, it is not known what use, if any, Quintus made of the catasterisms in his tragedy, which would in any case have been unlikely to share the concerns of an astronomical didactic poem.

On the other hand, there is plenty of evidence for Marcus' interest in astronomy, and his Aratea testifies directly to this interest, which seems to have remained constant throughout his career. ${ }^{47}$ Could Marcus, rather than Quintus, be the author of our fragment? Is it less likely that the lines in question have dropped out of the Aratea, than that either of the brothers composed a completely separate, although similar, astronomical work?

We might start by looking for a Quintus-sized hole in Marcus' Aratea. To begin at the same point as in my previous discussion, the list of Northern constellations, we saw that lines 17-20 of the Quintus fragment could stand as a translation of Aratus 50-2. Now it can be shown that a translation of Aratus 50-2 is in fact missing from the extant fragments of the early part of the Aratea, which are as follows (frr. 5-9 Soubiran, with my translations):

$\begin{array}{rr}\mathrm{V} & \text { (Arati versus) } \\ \text { quas nostri Septem soliti vocitare Triones } & \text { (post 27) }\end{array}$

which our countrymen are accustomed to call the Septem Triones

VI

ex is altera apud Graios Cynosura vocatur, altera dicitur esse Helice.

Of these, one is called Cynosura by the Greeks, the other is said to be Helice.

VII

hac fidunt duce nocturna Phoenices in alto; sed prior illa magis stellis distincta refulget, et late prima confestim a nocte videtur. haec vero parva est, sed nautis usus in hac est: nam cursu interiore brevi convertitur orbe.

The Phoenicians trust in Cynosura as a guide at night when they are on the deep; but Helice shines forth in front, more clearly picked out in stars, and is visible straight away everywhere at nightfall. Cynosura is small, to be sure, but useful to sailors because she completes a neat circle with more circumscribed course.

Greek models on the other. See D. R. Shackleton Bailey (ed.), Cicero: Epistuale ad Quintum Fratrem et M. Brutum (Cambridge, 1980), 4-5. For the testimonia on his works, see Buecheler (n. 4), 15-20. On the prose Commentariolum Petitionis, which may not be genuine, see now G. Laser (ed.), Quintus Tullius Cicero: Commentariolum Petitionis (Darmstadt, 2001), with review by R. Morstein-Marx in $C R 54$ (2004), 362-3.

${ }^{45} \mathrm{I}$ thank one of the readers for $C Q$ for raising this point. For the letters of Cicero referring to the Erigone, see D. R. Shackleton-Bailey (ed.), M. Tullius Cicero: Epistulae ad Quintum fratrem, Epistulae ad M. Brutum (Leipzig, 1988), 3.1.13, 3.5.7, 3.7.6-7.

${ }^{46}$ For the catasterism, see Hyginus, Poet. Astr. 2.149-209. On the Erigone of the Hellenistic poet Eratosthenes, see A. Rosokoki, Die Erigone des Eratosthenes (Heidelberg, 1995).

${ }^{47}$ See Gee (n. 2). 
VIII

has inter, veluti rapido cum gurgite flumen,

torvuu' Draco serpit supter superaque revolvens

sese, conficiensque sinus e corpore flexos.

Between these, just like a river with rapid torrent, savage Draco twines, curving himself above and below and shaping twisting coils out of his body.

IX

huic non una modo caput ornans stella relucet,

verum tempora sunt duplici fulgore notata,

e trucibusque oculis duo fervida lumina flagrant,

atque uno mentum radianti sidere lucet;

obstipum caput, a tereti cervice reflexum,

obtutum in cauda Maioris figere dicas.

There is not just one shining star adorning his head, but his temples are picked out by twin fires; two burning lights flare from his savage eyes, and his chin is illuminated by one radiant star. His head is inclined, bent back from his rounded neck; you might say that he was fixing his gaze on the tail of the Great Bear.

The fragments of Marcus Cicero given here cover the same ground as in Aratus' description of the relative positions of the Bears and Draco. Of particular interest to us are frr. VIII and IX. As the text stands, there is no translation in Marcus' Aratea of Aratus 50-2, the lines covered by Quintus 17-20. One gets a reasonably complete translation of Aratus' description of the Bears by inserting these lines between frr. VIII and IX.

In fr. VIII, Marcus is translating Aratus 45, 'in the likeness of a river' (= veluti rapido cum gurgite flumen), and Aratus 47-8, 'on either side of its coil the Bears move' (= has inter ... supter superaque). The rest of fr. VIII is composed of poetic additions to Aratus. Lines 17-20 of our fragment are no further from the Aratean text that this, and it is possible to say that both stylistically, and in terms of content, they would not look out of place in Cicero's text.

Turning to the Zodiac list, however, there is a problem. There is already a zodiac list in what we have of Marcus' Aratea, at lines 320-33:

$$
\begin{aligned}
& \text { aestifer est pandens ferventia sidera Cancer; } \\
& \text { hunc subter fulgens cedit vis torva Leonis, } \\
& \text { quem rutilo sequitur conlucens corpore Virgo; } \\
& \text { exin proiectae claro cum lumine Chelae, } \\
& \text { ipsaque consequitur lucens vis magna Nepai; } \\
& \text { inde Sagittipotens dextra flexum tenet arcum; } \\
& \text { post hunc ore fero Capricornus vadere pergit; } \\
& \text { umidus inde loci conlucet Aquarius orbe[m]; } \\
& \text { exim squamiferi serpentes ludere Pisces; } \\
& \text { quis comes est Aries, obscuro lumine labens, } \\
& \text { inflexoque genu, proiecto corpore, Taurus, } \\
& \text { et Gemini clarum iactantes lucibus ignem. } \\
& \text { haec sol aeterno convestit lumine lustrans, } \\
& \text { annua conficiens vertentia tempora cursu. }
\end{aligned}
$$

Cancer is the heat-bringer when he reveals his burning stars; shining below him, the savage powerful Lion proceeds. Virgo follows him, shining out with reddish form; then come the outstretched Claws with their bright light. Powerful Scorpio follows, then the Archer holds his bow flexed in his right hand; after him, fierce-visaged Capricorn proceeds apace. Next in position, watery Aquarius lights up the circle [of the Zodiac], then the twisting scaly Fish dart; Aries accompanies them, slipping along with dim light, and Taurus on bent knee, body inclined, 
and the Twins emitting a clear light from their stars. On these the shining sun endows his eternal light as he accomplishes with his course the changes of season from year to year.

Does the duplication of Zodiac lists mean that the Quintus fragment cannot come from the same work as the list just quoted? Not necessarily. In fact, the very similarity of the two lists might facilitate their use in structuring a single work, by variatio and recall. The beauty of lists is that they can be manipulated in different ways, and that is why we never get tired of them. The astronomical tradition is one of the best expressions of their malleability. In Aratus and his translators, lists of stars are repeated in various forms. The Phaenomena itself is composed of three lists. First the stars are placed on a map, as if visually (the $\Phi_{\alpha \iota \nu} \mu \epsilon \nu \alpha$, lines 1-450); then they are set in motion, as though the armillary sphere is now being rotated, with the simul-

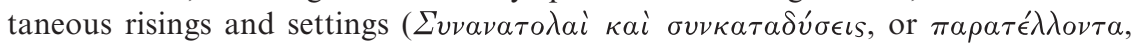
451-732); finally the weather-signs are listed (the $\Delta \iota$ เ $\eta \mu \epsilon \hat{\imath} \alpha, 733-1154) .{ }^{48}$ The same stars are already combined and recombined in different contexts. Lists can in addition acquire new elements as the tradition snowballs: thus Avienius' Aratea is 1875 lines long, as opposed to the 1154 of the original.

The zodiac list was subject to particular variation because of its seasonal, astrological and educative value. The Zodiac is a circle: one may begin it at any point according to the use one is making of it. In Aratus, and in Marcus Cicero, the zodiac list begins with Cancer, in 'Quintus' with Pisces. ${ }^{49}$ To begin with Pisces in a seasonal poem is perhaps more logical, since Pisces marks the beginning of Spring. On the other hand, the reason why Aratus began from Cancer and not Aries, as was the tradition in Egypt and elsewhere, was flagged by the scholia: although the Egyptians began the Zodiac with Aries, Aratus always starts his lists from as far North as possible, and Cancer is the northernmost of the Zodiacal constellations. ${ }^{50}$ Aratus' list was orientated according to geographical concerns; Quintus' list is orientated according to meteorological ones.

It would not be without parallel to vary the list in the same poem. There are no less than four separate listings of the Zodiac in Germanicus' Phaenomena, presenting interesting problems of structure and transmission. ${ }^{51}$ Here is a summary of the zodiac lists in Germanicus' translation of Aratus, as they appear in the texts of two different editors, Bresig and Gain: ${ }^{52}$

\section{Bresig:}

1. First Zodiac list: lines 531-64 in main text (haec via solis erit bis senis lucida signis. I nobilis hic Aries...).

48 The structure given here is that of Soubiran (n. 38), 8-9, n. 4.

49 The Zodiac list in Ausonius, Ecl. 9 begins with Capricorn.

50 E. Maass (ed.), Commentariorum in Aratum Reliquiae (Berlin, 1898; repr. 1958), 446: $\delta \iota \dot{\alpha} \tau i$

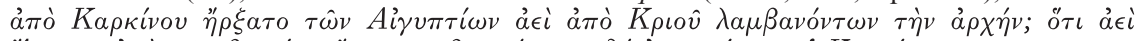

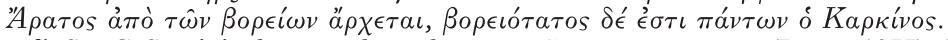

${ }_{51}$ See C. Santini, Il segno e la tradizione in Germanico scrittore (Rome, 1977), 15-22. Possanza (n. 36), 173-86, does not raise questions of authenticity in his discussion of Germanicus' first Zodiac list, merely noting that it represents the later poet's largest contribution of new material to Aratus' Phaenomena. One should add 'extant' here, since what appear to have been substantial passages on the influences of the planets on the zodiacal signs, a topic not treated in Aratus, are fragmentary (frr. 2-4 Gain).

52 A. Bresig (ed.), Germanici Caesaris Aratea (Leipzig, 1867; repr. Hildesheim, 1967); D. B. Gain (ed.), The Aratus Ascribed to Germanicus Caesar (London, 1976). 
2. Interpolated Zodiac list, $565-7$ in main text (Lanigeri . . .)..$^{53}$

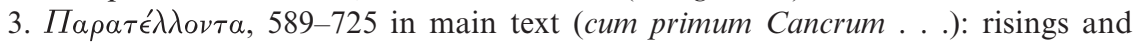
settings of other constellations, occurring simultaneously with certain signs of the Zodiac.

4. Prognosticorum Reliquiae: fr. 1, lines 1-39 repeat the first Zodiac list (=main text 531-69) with an extra line, 40, una via est solis bis senis lucida signis, which is very close to 531 .

5. Fr. 2, Meteorological Zodiac list, beginning grandine permixtas Aries nivibusque caducis.

Gain:

1. First Zodiac list: lines 531-64 in main text (haec via solis erit bis senis lucida signis. I nobilis hic Aries...).

2. Interpolated Zodiac list, 565-7 in main text (Lanigeri . . .).

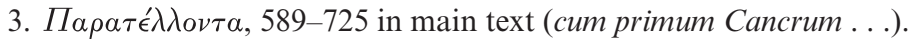

4. Fr. 3, Meteorological Zodiac list (grandine permixtos Aries ....).

We can see that there are significant differences between the texts given by the two editors, the most prominent being the repetition of thirteen lines in the text of Bresig, who explains the repetition by scribal contaminatio of 531 with Prog. fr. $1.40 .{ }^{54}$ Bresig thought that the Zodiac list of 531-64 was originally situated in the Prognostica. In favour of this idea, he cites differences between this list and that in Aratus, Phaenomena 544-52, which began from Cancer rather than Aries, as in Germanicus,

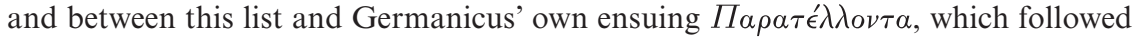
the order of the model in beginning from Cancer. ${ }^{55}$ But to place lines 531-64 in Germanicus' Prognostica is to create further problems: (a) there is now no zodiac list in the main text to translate Aratus 544-52; and (b) we end up with (at least) two zodiac lists in the Prognostica, since we already have fr. 2 (Bresig)/3 (Gain), so we have not made the re-duplication go away, rather brought two instances of it into closer proximity with one another.

More recently, Carlo Santini has argued strongly for the authenticity in its existing location of Germanicus' first Zodiac list. ${ }^{56}$ There is no reason why Germanicus cannot be varying Aratus' list along the Egyptian principles cited by the scholia, ${ }^{57}$ thereby updating his text according to the scholastic tradition, but later in his text

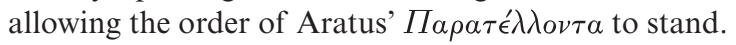

Whatever factors of transmission may be in operation, it is clear that there is internal variation of Germanicus' zodiac lists: three begin from Aries, one from

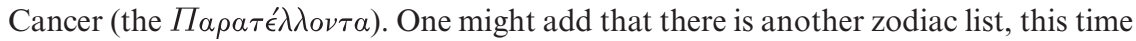
commencing from Taurus: fr 3 (Bresig)/4 (Gain), on the influence of the planets on

53 See Bresig (n. 52), vi; Gain (n. 52) on lines 526-9; Santini (n. 51), 16.

54 Bresig (n. 52), xi.

55 Bresig (n. 52), xif. ornatissimus et splendidus de circulo zodiaco locus . . quem si cum tenui signorum enumeratione Aratea comparaveris, inusitatam Germanico mirabere magniloquentiam atque ordinem astrorum cum ab ipsius tum ab Arati more diversum. His 'restoration' of 531-64 to the Prognostica also helps him to deal with the problem of lines 558-60, which appear to have been written after Augustus' death: he says that Germanicus' Prognostica could have been written/edited later than the Phaenomena.

56 Santini (n. 51), 16.

57 Above, n. 50. 
the zodiac. Germanicus seems to be deliberately playing the list game, rather than simply avoiding altering his 'original'. His intention might plausibly have been to have three zodiac lists (to omit the 'spurious' one at lines 565-7), the first two of which (the First Zodiac list and the $\Pi \alpha \rho \alpha \tau \epsilon ́ \lambda \lambda o \nu \tau \alpha$ ) correspond in form and function, though vary in precise detail, to those found in Aratus' poem ${ }^{58}$ the third of which (fr. 2 Bresig/3 Gain) embroiders an element only implicit in Aratus, the Zodiac as a tool of weather-prediction.

It is this third list, Germanicus fr. 2 (Bresig)/3 (Gain), the place of which among the fragments of the Prognostica is not a matter for dispute, which is of greatest interest to us. I quote Gain's text and translation:

grandine permixtos Aries nivibusque caducis

vicina aspergit tristis supra iuga nimbos.

Taurus portat aquas et ventos excitat acres;

fulmina tum crebro iaculatur Iuppiter et tunc

intonat emissis violentior ignibus aether.

at Geminis leviter perstringunt caerula venti,

rarus et in terras caelo demittitur umor.

omnia mitescunt tranquillo sidere Cancri.

siccus erit Leo, praecipue cui pectora fervent.

Virgo refert pluvias et permovet aera ventis.

lenius est Librae signum; vix rorat in illo.

Scorpios assidue caelo minitabitur ignis

atque truces ventos; densa nive saepe rigebunt.

rara Sagittifero descendunt flamina terris; $\quad 15$

lentior in pluvias, magis invenit arva quieta. 13

Aegoceros alias parcit, sed frigora durat,

instabilita gelu falli vestigia passus.

qui fundit latices caelo quoque permovet imbris.

omnia miscentur cum Piscibus; aspera ventis

aequora turbatos volvunt ad sidera fluctus;

imbribus incumbit caelum solemque recondit;

grandine pulsatur tellus, nive condita dura est.

The Ram scatters dreary rain mixed with hail and falling snow over the nearby ridges. The Bull carries water and arouses violent winds. Under him Jupiter often casts his thunderbolts, (5) the sky is violent, fires are sent from it, and it thunders. Under the Twins winds gently caress the azure sky and moisture seldom travels down from sky to earth. Everything grows mild under the peaceful sign of the Crab. The Lion is dry, seeing that his breast is particularly hot. (10) The Maiden returns water and stirs the air into activity with winds. The Balance is a gentle sign; scarcely even dew falls under it. The Scorpion continually threatens the sky with fierce winds; they are often stiff from the dense snow. (15) Under the Bow-Bearer breezes seldom descend to earth; he is milder as regards rain and finds the earth quieter. Capricorn spares in other respects, but hardens the cold, permitting men's feet to become unsteady and slip on the ice. The being who pours forth water also excites rain in heaven. Under the Fishes everything is mixed together: (20) the sea, churned up by the wind, rolls its seething waves towards the stars; the sky is heavy with showers and hides the sun, the earth is smitten by hail and covered by hard snow.

Preserved only in the $\mathrm{Z}$ family, ${ }^{59}$ this Zodiac list is constructed on the same meteorological principle as that of the Quintus fragment. Note especially the similarity of Germanicus' description of Aegoceros (Capricorn) with Quintus line 12, and his evocation of the Fish as accompanied by turbulent water at 19-20. A parallel for the

58 Gain (n. 52) ad loc.: '531-64 expand Aratus 545-9, which simply list the Zodiacal signs'.

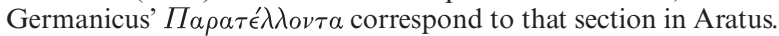

59 See Gain (n. 52), 124. 
concrete use of frigora in Germanicus' line 16 is found at Quintus line 11, Sagittipotens iaculatur frigora terris.

At the very least, it is clear that the Quintus list belongs in the same prognostic tradition as Germanicus fr. 2 (Bresig)/3 (Gain). ${ }^{60}$ Might this support a hypothesis that it belongs in the second part of Cicero's Aratea, the Prognostica, as the meteorological doublet of his Zodiac list at Aratea 320-33?

Cicero's Prognostica as extant does not contain lines on the stars as weather-signs, but it is in a pretty poor state. How likely is it that Cicero's Prognostica contained star-signs? Quite likely, it seems to me. Aratus and Virgil both include stars in their lists of weather-signs. At Phaenomena 740-51 the stars find a place in the introductory passage to Aratus' Diosemeia:

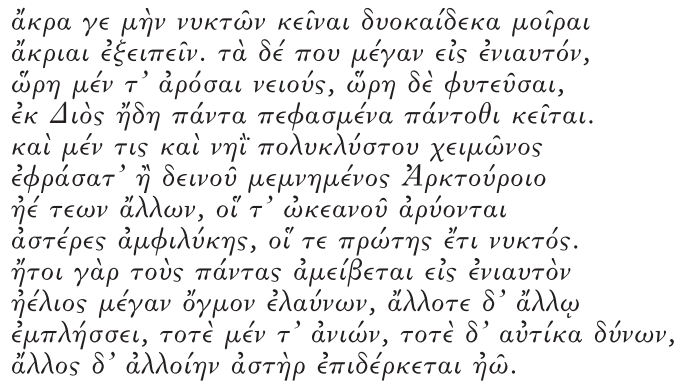

For declaring the endings of nights those twelve signs of the zodiac are certainly reliable. But as for the times of the great year, the time to plough fallow land, the time to plant trees, these are already available as revealed by Zeus. Also many a man aboard ship has noticed signs of a surging storm by paying heed to either dread Arcturus or some other stars that are drawn from the ocean at morning twilight and when it is still early night. In fact the sun overtakes them all throughout the year as he drives his great swathe, and impinges on different stars at different times, now at his rising and now again at his setting, and so different stars look down on different kinds of day.

Although the signs of the zodiac are not here explicitly referred to as weather-signs, the named constellation, Arcturus, is a weather-sign, and what follows in relation to the sun applies specifically to the zodiac, since on it is the path of the sun, the ecliptic (see Cicero, Aratea 332-3, quoted above). After the quoted passage, Aratus reminds us in summary form of the star-map and the signs it offers (752-7). At Phaenomena 892-908, Aratus includes among his weather-signs the Manger ( $\left.\Phi_{\alpha}^{\prime} \tau \nu \eta\right)$ and the Asses ('Ovo $)$. The Manger reappears as a sign of good weather at 995-8. Dim stars are, unsurprisingly, a sign of impending storm at Phaenomena 1013-18. In these passages, it is not suggested that the stars bring specific weather, merely that the observation of them enables prediction; but at Phaenomena 1084-5, the Pleiades do

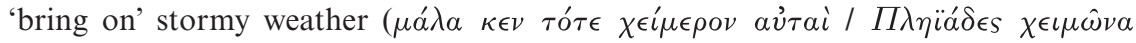
$\kappa \alpha \tau \epsilon \rho \chi o ́ \mu \epsilon \nu \alpha \iota$ форє́́ $\iota \epsilon \nu)$.

The stars move to a more prominent position in Virgil, who introduces a greater number of constellations than Aratus into his prognostics at Georgics 1.204-14, also giving Libra an active role to play in the seasons:

${ }^{60}$ I shy away from attributing yet another zodiac list to Germanicus! But that is not to say that the Quintus fragment might not in theory merit examination in relation to the tradition of Germanicus as much as that of Cicero. 
praeterea tam sunt Arcturi sidera nobis

Haedorumque dies servandi et lucidus Anguis,

quam quibus in patriam ventosa per aequora vectis

Pontus et ostriferi fauces temptantur Abydi.

Libra die somnique pares ubi fecerit horas

et medium luci atque umbris iam dividit orbem,

exercete, viri, tauros, serite hordea campis

usque sub extremum brumae intractabilis imbrem;

nec non et lini segetem et Ceriale papaver

tempus humo tegere et iamdudum incumbere aratris,

dum sicca tellure licet, dum nubila pendent.

We must especially observe the star of Arcturus, and the days of the Kids, and the shining Serpent, as do they who, sailing home across the windy sea, brave the Pontus and the oyster-growing gulf of Abydus. When Libra has made equal the hours of day and of sleep and has already divided the world down the middle with light and shade, then, men, drive on your oxen, sow barley in the fields, right up to the beginning of harsh winter's rain; then also is the time to cover with earth the crop of flax and the poppy of Ceres and forthwith to bend to the plough, while the dry earth permits and the clouds hang in the balance.

Neither Aratus nor Virgil has a complete Zodiac list among his weather-signs, but it is easy to see how Aratus' text might point the way to including a prognostic zodiac list in an Aratean poem, as Germanicus apparently does. One could argue that Cicero's Prognostica might have influenced Virgil in amplifying the stars in his section on weather-signs. It is perhaps anomalous that the latest Roman translator of Aratus, the fourth century poet Avienus, does not reduplicate the zodiac list in his Prognostica, although he does digress on the planets (notably not treated in his Hellenistic model) at Phaenomena 1509-17. Germanicus seems to have varied Aratus more than Avienus, taking liberties with his source-text which the later author was not prepared to take. One explanation for this seeming anomaly might be that Germanicus also had in fromt of him the precedent offered by Cicero's Aratea, which Avienus may no longer have had. ${ }^{61}$ If Germanicus varied his original by duplicating the Zodiac list from his Phaenomena in his Prognostica, why should Cicero not have done the same?

Moreover, if Cicero's Prognostica contained a second zodiac list embroidering the sketch of Aratus Phaenomena 741-51, the Quintus list would fit, since its overriding idea is of the stars as weather-signs. It would be easy to see why this list became separated from the rest of the Prognostica, as (a) it might be felt to be otiose, given the zodiac list in the first part of Cicero's Aratea, and (b) it would be a perfect candidate for excision because of its scholastic value as a mnemonic list of signs of the Zodiac, in the same way Cicero's 'original' Zodiac list at Aratea 320-33 was excerpted. ${ }^{62}$

On top of these arguments, there exists some external evidence as to Marcus' authorship of our fragment. The word arcera in line 18, the only instance in Latin of that word used of the Great Bear, attracted the attention of Nonius Marcellus, writing in the first half of the fourth century, who glosses it as follows:

61 See n. 81 below.

${ }^{62}$ Cicero's list was anthologized in the time of Bede and attributed to Bede himself as Bedae de duodecim signis zodiaci in Trinity College 0.2.24 (C12th): see M. D. Reeve, 'Aratea', in L. D. Reynolds (ed.), Texts and Transmission, (Oxford, 1983), 18-24, at 23; V. Buescu (ed.), Cicéron, Les Aratea (Bucarest, 1941; repr. Hildesheim, 1966), 105-6. Cicero's list was also placed alongside one of Ausonius' Eclogues, probably in the early Middle Ages, in a little astronomical anthology (Peiper [n. 3], xxxi). 
Arcera plaustrum est rusticum tectum undique, quasi arca. hoc vocabulum et apud Varronem et apud M. Tullium invenitur. hoc autem vehiculi genere senes et aegroti vectari solent. ${ }^{63}$

'Arcera' is a rustic wagon covered on all sides, like a box. The word is found in Varro and Marcus Tullius (Cicero). Old or sick people are usually carried in this type of vehicle.

It has been thought that Nonius attributed this line to Marcus, rather than to Quintus, in error. ${ }^{64}$ Indeed, the word arcera is not used elsewhere in Marcus' works; nor is it in Quintus'. ${ }^{65}$ But the Nonius reference could also be explained in other ways. For example, what if Marcus did use arcera, possibly somewhere in the lost lines of the Aratea? The fact that Arcera is used of the Great Bear only here in Latin might be consonant with Marcus' innovative Latinizing of Greek star-names in a manner harmonious with Roman tradition. If the term in Marcus referred to the Bears, as it does in the Quintus fragment, it would almost certainly have occurred in the earlier part of Cicero's Aratea, which is not extant.

There follow two possibilities: Quintus imitated Marcus' innovative star-name, like so much else from the Aratea, in his own astronomical poem, of which our fragment is all that remains; or, alternatively, Nonius is right, and Marcus, not Quintus, is the author of this poem, lines 17-20 of it belonging in the earliest part of the Aratea, lines 1-16 in the Prognostica. To my mind, the latter alternative has the benefit of greater economy of argument, in that it is preferable to attribute lines on astronomy to a work we know exists, rather than to attribute a whole new astronomical work to Quintus without conclusive evidence.

What is the result of all this for the dating of our fragment? If it belongs in Cicero's Prognostica, we must date it to $c .60$ B.C., when Cicero's Prognostica was written or an earlier version revised. ${ }^{66}$ If there was an earlier version, contemporary with the original composition of Cicero's Aratea, and our fragment was in this earlier version, its original date of composition might be as early as 89 B.C.

With this proposition in mind, let us look in more detail at the reasons scholars have assigned our fragment to 45-43 B.C. This is done largely on the basis of the use of Libra in line 9, instead of the Greek Chelae (the 'Claws' of Scorpio). ${ }^{67}$ Our fragment may be the earliest attestation of Libra as the name of a star-sign in Latin poetry. The first datable reference in Latin appears to be Varro, De Lingua Latina 7.14, signa quod aliquid significant ut Libra aequinoctium ('Star-signs are so called because they signify something, as Libra does the equinox'). Assuming that this passage, composed $c .45$ B.C., both antedates the Quintus fragment, and that Varro's is our earliest reference to Libra, Possanza gives a terminus post quem coinciding with Varro's reference, and a terminus ante quem with Quintus' death in 43.

Since Possanza attaches importance to the name Libra in the dating of our fragment, we need to examine its history. The 'Claws' of the large constellation

63 Nonius Marcellus, De Compendiosa Doctrina, ed. Lindsay, 77.

${ }^{64}$ Courtney (n. 4) on Quintus line 18. Thus also TLL 'Arcera': 'Q. Cic. fr. 1.18, quem locum Non [ius] p. 55.2 errore ad M. fratrem refert.' See also Buechner (n. 4), 102, in the apparatus: $M$. et $Q$. fratres confudit Non.

${ }_{65}$ Checked in BTL-2 CD-ROM (2002); cross-checked in M. Merguet, Lexikon zu den philosophischen Schriften Ciceros, vol. 1 (Hildesheim, 1961), and K. M. Abbot, W. A. Oldfather and H. V. Canter, Index Verborum in Ciceronis Rhetorica,(Urbana, 1964).

${ }^{66}$ For the date, see Soubiran (n. 38), 9-16. In a letter to Atticus of June 60 B.C. (Att. 2.1.11), Cicero writes Prognostica mea cum oratiunculis propediem expecta.

${ }^{67}$ Possanza (n. 35), 45f. 
Scorpio are referred to as $X \eta \lambda \alpha i$ in Greek from about the fifth century B.C. ${ }^{68}$ The concept of the 'Balance' is late in Greek: it is unknown to Eudoxus or Aratus (who always used $X \eta \lambda \alpha i$ ), and not until Ptolemy (with any certainty) do we find the Claws

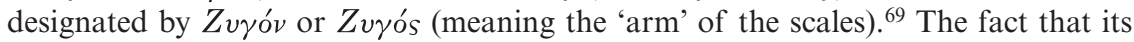
semantic calque Iugum is used by Cicero at De Divinatione 2.98, may indicate that $Z v$ yós is in use by his time, although we do not know whether the Greek name came first or whether it was a first-century innovation in response to the Roman Libra.

André le Boeuffle thought that the Autumn equinox took place with the sun in Libra in this period, and that this was one reason why the name Libra caught on, for reasons discussed above in relation to Quintus' imagery. But on equinoctial grounds it might be argued that an earlier date for any excitement about Libra is more appropriate, since in 70 B.C. the equinoctial point was in fact about to pass out of Libra, where it had rested since $c .2237$ B.C. In any case, it was probably not the change of equinoctial point which precipitated the development of the name Libra, since the change of equinoctial sign passed unremarked by most astronomers. ${ }^{70}$ The main thing is that, as far as Libra is concerned, the concept, and the name, could in theory have already been around for some time by $c .45$ B.C., and would be around for some time to come. For this reason also, we cannot be sure that Marcus did not use it in the non-extant parts of his Aratea in place of Chelae, despite Possanza's assertion to that effect. ${ }^{71}$ Varro's may not be the earliest reference to Libra in Latin. Like the vast majority of Roman star-names, including Arcera, which did not, however, share its success, it may have come into Latin with Cicero's Aratea (or, to be precise, Prognostica). As a result, our terminus post quem for both the name Libra, and for the Quintus fragment, must be moved back to at least 60 B.C., and possibly as far back as c. 89. The simplicity of its system of nomenclature, its similarity to Marcus', and its emphasis on the agricultural and meteorological, rather than political, significance of the stars, especially in the case of Libra, might equally incline us towards placing the fragment early in the tradition of Roman astronomical literature. ${ }^{72}$

I contend that there is insufficient evidence for giving 45 B.C. as a terminus post quem for the Quintus fragment, and that certain factors point to a date earlier in the first century B.C., consonant with attribution of the poem to Marcus Cicero's Aratea.

68 See Le Boeuffle (n. 19), 170, and n. 2.

69 See Le Boeuffle (n. 19), 171.

70 Most astronomers in the late Republic and early empire used sidereal reckoning, rather than the tropical reckoning of longitude introduced by Hipparchus; and sidereal reckoning would have allowed the autumnal point to remain in Libra for about another 200 years. I am greatly indebted to John Ramsey and Stephan Heilen for clarification of my suspicions as to these matters; see also A. Jones, Astronomical Papyri from the Oxyrhyncus (P.Oxy. 4133-4300a), Memoires of the American Philosophical Society 233 (Philadelphia, 1999), 2 vols., at 1.343; O. Neugebauer and H. van Heusen, Greek Horoscopes, Memoires of the American Philosophical Society 48 (Philadelphia, 1959), 172.

71 In the extant part of Marcus' Aratea, Chelae is always found, and Possanza (n. 35), 45, maintains that Cicero would have used Chelae even in the instances missing from our present text: 'We can be sure of this because Cicero regularly glosses Greek names with their Latin equivalents and prefers the native to the foreign name.' In this respect too, I would argue that we cannot be so certain: sometimes Cicero deliberately plays with variation between Roman and Greek names. For example, at Aratea 28, the old Roman name for the Pleiades, Vergiliae, clashes with the highly Greek names of the individual Pleiades which follow in lines 35-6.

72 Later, the sign was associated with justice (Virgil, Ecl. 4.6, G. 2.472), and Augustus was said to have been born under this sign (Manilius 4.547-52). See also Manilius, Ast. 4.776f., where Augustus' function in bringing equilibrium to the world is assimilated to that of Libra: qua genitus Caesar melius nunc condidit urbem / et propiis frenat pendentem nutibus orbem. 
This must be taken with previous reconsideration of the evidence for attributing the fragment to Marcus, not least Nonius' reference.

We have so far been assuming that Ausonius was responsible for the 'error' of attributing our fragment to Quintus. If this is so, why Ausonius might have made this particular 'error' remains a mystery, but one which (in my view) can be plausibly explained by the arguments advanced above: he did not understand how there could be two zodiac lists in the one poem of Marcus, and so attributed our fragment to Quintus, because of its closeness to Marcus' Aratea, and perhaps because of his knowledge that Quintus had at least some astronomical interests, as evinced by his Erigone.

But what if Ausonius himself was not the excerptor of our fragment? No less an authority than Scaliger believed Ausonius himself to have been Quintus' excerptor, ${ }^{73}$ but this merits some scrutiny. How plausible is it to assume that Ausonius had a full copy of the text of Cicero's Aratea in front of him? Our knowledge of the Aratea in the years between the first century B.C. and the fourth century A.D. is patchy at best, our earliest manuscript $(\mathrm{H})$ dating to the ninth century. From other sources it is reasonably clear that Virgil, Ovid, Germanicus and Manilius knew Cicero's Aratea. ${ }^{74}$ According to Soubiran, it is likely that Hyginus, writing perhaps in the Augustan era, had a complete text (if the De Astronomia and Fabulae are indeed by the freedman of Augustus). ${ }^{75}$ Pliny the Elder quotes Prognostica fr. 5 (Soubiran) at $H N 18.228 .{ }^{76}$ In $c$. 180, the young Gordian apparently re-vamped the Aratea, along with the other poems of Cicero, if Julius Capitolinus is to be relied upon. ${ }^{77}$

In the early fourth century, Lactantius may have had an extant version of the Aratea, since he cites Cicero twice in his discussion of the 'Golden Age' (Divinae Institutiones 5). ${ }^{78}$ One could argue that Lactantius had a complete copy open on his desk, because his references are here in close proximity to one another, perhaps indicating comparative reading of Cicero and Germanicus, who is cited in the same passages. ${ }^{79}$ Alternatively, since all his quotations come from Cicero's and Germanicus' translations of Aratus' famous purple passage on Dike, he may already have been drawing on some kind of anthology. Although he was also writing in the fourth century, Avienus was apparently devoid of any knowledge of Cicero's Aratea: 'Aviénus retraduit Aratos avec une prolixité où ne se reconnait aucune trace de la version ciceronienne' ${ }^{80}$

73 See Buecheler (n. 4), 20.

74 Soubiran (n. 38), 83-5.

75 Soubiran (n. 38), 84. Hyginus quotes Aratea fr. 10 (Soubiran) at Poet. Astr. 4.3, Aratea line 17 at Poet. Astr. 3.29, and lines 126-38 at Fab. 14.

76 See Soubiran (n. 38): 84.

77 H. Peter (ed.), Scriptores Historiae Augustae, 2 vols. (Leipzig, 1884), 2.31 adulescens cum esset Gordianus . . poemata scripsit, quae omnia extant, et quidem cuncta illa quae Cicero, id est Marium et Aratum et Halcyonas et Uxorium et Nilum. Quae quidem ad hoc scripsit, ut Ciceronis poemata nimis antiqua viderentur. See Soubiran (n. 38), 6, n. 6.

78 Div. Inst. 5.5 and 5.9 (= Cic. Arat. fr. 18 and fr. 19 Soubiran). See Soubiran (n. 38), 85.

79 Div. Inst. 5.5 = Germanicus, Arat. 112-13 Gain; Inst. 5.9 = Arat. 137 Gain.

${ }^{80}$ Soubiran (n. 38), 83. Of the grammarians, Servius quotes the Aratea only once (on $G$. 1.111), Probus twice (Keil, Grammatici Latini 4.223). In the sixth century, Priscian has no fewer than fourteen references, making it more certain that he had a complete text, including the Prognostica (references to the Phaenomena at Keil, Grammatici Latini 2.211 (bis), 218, 247, 285, 351, 504; 3.30, 55; to the Prognostica at 2.196, 504; 3.105, 287. Buescu (n. 62), 100, believes that Priscian had a copy of Cicero's Prognostica as well as his Phaenomena. It is uncertain whether Isidore in the seventh century is quoting at first hand (Etym. 12.7.31 Lindsay: Cicero in Prognosticis, 'et matutinos exercet acredula cantus'). 
Given the patchy and often conflicting evidence, it is difficult to be certain whether Ausonius would have had a complete text of the Aratea. The Aratea was probably a school text from early on, and Ausonius was a rhetorician and teacher. But the form in which the text may have been presented is uncertain, and it is perhaps likely that certain excerpted passages would have been memorized. As we have discussed above, the zodiac passage(s) were particularly likely candidates for early excerption. The considerable interest in Aratean translations in the fourth century and later is not necessarily based on a direct knowledge of the texts themselves, but, as some contend, on a knowledge of the exegetical tradition which early surrounded them. ${ }^{81}$

If our fragment did indeed come from a larger work such as Marcus' Aratea, it is quite likely already to have been excerpted by $c$. 490, the approximate date of Ausonius' Eclogues. ${ }^{82}$ We do not need to assume that Ausonius is both excerpting and attributing our poem. The possibility that one or both of these things already been done from him would make it more likely that he was transcribing the error of someone else.

Such speculation is dangerous, not least in that it widens the field of authorship almost without limit. If our fragment has been ascribed to Quintus in error, we can admit the possibility that it was written by Marcus. But we must also admit the possibility that it could have been written by neither of the Cicerones, but by someone else working after $c .89$ B.C. and before A.D. c. 490, someone familiar with the language and idiom of the Aratea and learned enough to produce a pastiche of or sequel to it. Such a hypothesis is not precluded by what we know of the vicissitudes of the Aratea from the first to the fourth centuries A.D. At some stage our poem was ascribed to Quintus, and its traditional attribution was set. This may be highly speculative, but it simply takes to extreme the point of the foregoing discussion, which is that, once Quintus ceases to be the author of our fragment, the accepted dating of it must be discarded. In the foregoing discussion, we have argued for an earlier terminus post quem; a new terminus ante quem might be c. 490, the date of Ausonius' Eclogues.

Were it not for the phrase nostris versibus in the Ausonian superscription, which has been taken by editors to represent Ausonius himself referring to similar material in his own Eclogues, the terminus ante quem could be stretched to as late as the writing of $\mathrm{V}$ in $c$. 800. A parting shot at this might be worthwhile. Two questions are involved: does the superscription have to be authorial, and nostris versibus have to refer specifically to the Eclogues?

On the first question: if this particular superscription is authorial, then it is a special case. V is an anthology of Ausonius' works, and there are signs that a selection, or several selections, have been made by someone other than the author. ${ }^{83}$ The title of the collection-Eclogae - is unlikely to derive from Ausonius himself. ${ }^{84}$ Sometimes the poems have superscriptions which are clearly not authorial: for example, in the heading to the unfinished fragment Pater ad Filium we are given historical background to the poem, together with the information that the work was found incomplete among Ausonius' rough drafts; ${ }^{85}$ and in the heading to De

${ }^{81}$ Soubiran (n. 38), 143, believed that it was the tradition of exegesis of the Aratea, which seems already to have existed in the second and third centuries A.D., rather than Cicero's translation itself, which prompted Avienus to essay his own, more ample, translation.

${ }^{82}$ See Green (n. 3), 421.

${ }_{83}$ Peiper (n. 3), viii: 'ne hic quidem liber (ie.V) omnia servavit, quae archetypus conplectebatur'; see also Green (n. 3), xlvii.

${ }^{84}$ Green (n. 3), 421.

${ }^{85}$ Green (n. 3), 285 describes this superscription as an 'editorial note'. 
Herediolo, there is a reference to Ausonius in the third person. ${ }^{86}$ There exists variation in the superscriptions wherever they are preserved in more than one part of the tradition. ${ }^{87}$

Green sees the inclusion of our fragment among the Eclogues as militating against the authorial arrangement of the poems: in his view it was 'evidently copied out by Ausonius when working on the poems, and also suggests that he did not oversee the final collection' ${ }^{88}$ We are evidently to envisage our poem being tucked in as Ausonius composed using a codex notebook; or perhaps Ausonius jotted the lines down on a small writing tablet, along with his own poems, whence it and they were copied into the final codex (the form in which the work is likely to have been published). ${ }^{89}$

If the superscription to our fragment is not authorial, there are two possibilities as to its origin. One of these might be that the loose leaf on which our fragment was written already contained the superscription, and the superscription is not by Ausonius but by whoever wrote the Quintus fragment, referring to his quotation of a larger Aratean work in a context lost to us. 'Superscriptions' of a similar kind are in fact commonplace in Cicero's quotation of other works, including of his own Aratea and Prognostica in the De Natura Deorum and De Divinatione. Conversely, the superscription may provide an editorial 'reading', later than Ausonius, of that author's supposed intentions in including our fragment in his collection, combined with a hazy knowledge of which of the Cicerones wrote the Aratea, to which it is so clearly related. The attribution might then originate with whoever edited Ausonius' poems for publication at the end of the fifth century. Could nostris versibus represent either the editor's gloss on the author's intention, or be a reference to the verses which he as editor is dealing with?

To my mind, the question of the superscription cannot be satisfactorily resolved; it is best to live with a lesser degree of certainly as to the authorship of the superscription than might at first seem warranted. If the superscription is not by Ausonius, it may be that there is congruently less reason to assume that whoever first edited Ausonius' poems for publication also wrote the superscription. The person who identified Quintus as the author of our little poem might have been at work any time up to $c .800$. Confusion as to which of the brothers wrote the astronomical poem to which our fragment is related is perhaps more likely at a later date, when it is almost certain that scholars would not have had access to Cicero's Aratea.

What was the state of the text of Cicero's Aratea in the centuries between $c .490$ and c. 800 ? The main problems in the later history of the text of the Aratea are the date at which the mutilation occurred, which left only 480 lines extant, and when the text of the Prognostica disappeared. We cannot fix a certain date for the edition of the

${ }^{86}$ Green (n. 3), 19.

${ }^{87}$ E.g. Ecl. 2 is Monosticha de mensibus in V, but de singulis mensibus in b; Ecl. 11 is De temporibus in M, De Temporibus Monosticha in E, De temporibus anni in $\mathrm{K}$ and De mensibus et quattuor anni temporibus in $\mathrm{CT}$; Ecl. 19 carries the superscription ex graeco pythagoricon de ambiguitate eligendae vitae in V, incipit egloga eiusdem de ambiguitate vitae eligendae iuxta graecum . . . in P, egloga de ambiguitate vitae eligendae incipit in a, etc; and 20 is called De viro bono pythagorice atioasis in V, De institutione viri boni in GWYJl, and has no title in I. It is clearly unlikely that all of these variants are authorial.

${ }^{88}$ Green (n. 3), 421.

89 If Ausonius were composing into a codex-notebook, the normal medium for rough drafts, it might be easy for him to tuck the Q. Cicero fragment in a few pages after $E c l$. 9. The fragment might then have been included in the process of publication, when the manuscript notebook of Ausonius' poems was handed over to a bookseller for copying. On the publication process, see P. Howell, A Commentary on Book One of the Epigrams of Martial (London, 1980), 106. 
text from which our MSS are derived; Buescu and Soubiran, largely on the basis of Priscian's citations, believe it is likely that Cicero's work existed in its entirety until the sixth century. ${ }^{90}$ Between the sixth and the ninth centuries, the initial and final folia of the archetype, including the Prognostica, became detached, leaving, by $c$. 800, the work we know. $\mathrm{H}$ of Cicero (Harleianus 647) probably represents faithfully an intermediate copy made between the sixth and eighth centuries; by the latter date the text was probably already fragmentary. ${ }^{91}$ I have noted above that Cicero's zodiac-list was anthologized at or before the time of Bede (c. 672-735). This may or may not mean that a complete text was available at that date: the zodiac list comes in the 480 lines which survive in the form in which we have the Aratea.

On the arguments advanced in this paper, the Quintus fragment would either have been excerpted before this falling-apart process, or it was one of the results of it. If the latter, how did it come to be stuck among the works of Ausonius? One answer, albeit a tentative one, is that the two traditions - that of the Aratea, and that of Ausoniuswere taking shape at the same time and in the same place. The tradition of both Ausonius and Cicero's Aratea seems to have taken root in north-eastern France in the second half of the eighth century or early ninth century. ${ }^{92}$ Perhaps it might have been at this stage that our fragment became embedded among the Eclogues of Ausonius; an explicatory superscription might have been added and incorporated into $\mathrm{V}$ at some stage before $c$. 800. This is to take the terminus ante quem of our fragment way beyond that of 43 B.C. offered by its attribution to either Quintus or Marcus Cicero.

Whatever conclusions can be drawn, we can see that our fragment does not stand alone, but must be considered in all of the possible contexts which might have given rise to it in its present form. We should not too greatly lament the triviality of Quintus' little astronomical poem. It has important things to say about the reading, interpretation and dating of fragmentary texts.

St Andrews University

EMMA GEE

ergg@st-andrews.ac.uk

90 Buescu (n. 62), 104; Soubiran (n. 38), 142.

91 Buescu (n. 62), 104, Soubiran (n. 38), 144. Soubiran casts doubt on the theory that a complete copy of the Aratea existed in Prüm as late as 847 (see also Buescu [n. 62], 102-4); in his view, Lupus of Ferrières was probably wrong in thinking that the lacunae in his copy could be filled by looking at the Prüm copy, in his letter to Ansbald: see L. Levillain (ed.), Loup de Ferrières: Correspondance (Paris, 1935), 2.4-6, no. 69; cf. Reeve (n. 62), 23.

92 On the Aratea, see Reeve (n. 62); on the provenance V of Ausonius, see Reeve (n. 1); Turcan-Verkerk (n. 1); Tafel (n. 1); Della Corte (n. 1). 